\title{
Flood Mitigation Policy Directive in East Lombok Regency West Nusa Tenggara Province
}

\author{
Matur Prasojo \\ Graduate Student of Geography Education, Faculty of Social Science,Universitas Negeri Padang. \\ Email : maturprasojo8@gmail.com
}

\begin{abstract}
This type of research belongs to the type of descriptive research. The method used in this research is Mixed Methods. Technique of data analysis in this research by using formula determined by criteria and for analysis of data of policy direction of flood mitigation using AHP. Sembalun Sub-district, East Lombok regency is an area with bad land characteristic and supports flood disaster, in terms of flood hazard level included in criteria of moderate flood hazard and has a total level of total risk. Policy priorities that can be considered in decision making in relation to flood mitigation in Sembalun sub-district, East Lombok regency based on 3 criteria that exist using AHP are 1) Based on land characteristic criteria, among others: a) Making permanent embankment, b) Dissemination and disaster simulation flood, c) Provision of flood posts.2) Based on the criteria of disaster response community, among others: a) Establishment of early warning system, b) Disaster flood socialization and simulation, c) Provision of flood posts. 3) Based on the criteria of flood risk level, among others: a) Making permanent embankment, b) Disaster flood socialization and simulation, c) Provision of flood posts and building early warning system.
\end{abstract}

Keywords: Policy Direction, Disaster Mitigation, Flood

\section{Introduction}

Indonesia is a country that is in the circumcision of the world's volcanoes, where this circulation spread from west to east of Indonesia. Indonesia is also an archipelagic country with the potential to be vulnerable to the threat of various types of disasters, including the threat of natural disasters. Natural disasters are all kinds of natural phenomena whose sources, behaviors, and factors or effects come from events or series of natural events that can result in environmental damage and destruction and can ultimately lead to loss of life and loss of property. Natural disasters occurring due to excessive exploitation of natural resources of soil, forests and water as well as changes in weather or global climate have resulted in increased critical land, in addition the impact will change the use of water, resulting in floods, droughts, landslides, forest fires and land and the increasing rate of erosion and sedimentation (Indradewa, 2008), also called hydrometeorological disaster.

Hydrometeorological disaster is a disaster caused by damage to the system in the hydrological cycle, thus affecting the stability of climatic conditions and water reserves on the earth's surface. Conditions of rainfall irregularities, inconsistencies in rainy and dry season variations, loss of hydrological functions of watersheds, loss of millions of hectares of forest due to illegal logging, resulted in ongoing land degradation in floods and landslides (Hermon, 2012). Natural disasters that cause massive damage and loss and always threaten some areas in Indonesia one of the natural disasters are floods. Flood disaster is an event or series of events that threaten and disrupt the life and livelihood of the community caused by overflowing river water caused by natural factors due to damage to buffer zone in upper das (watershed) area resulting in human casualties, environmental damage, loss possessions, and psychological effects (Paimin et al., 2009 in 
Hermon, 2012). Flood disaster almost every rainy season hit Indonesia, not to mention the flood disaster also hit East Lombok regency.

East Lombok regency has a beautiful natural scenery with a cool climate, also prone to natural disasters. Based on the history of the incident in East Lombok there are 11 types of disasters identified but from the 11 types of disasters earlier, the flood disaster became a routine disaster in this area. The percentage of total disaster incidence in East Lombok Regency from 1990-2015 is: 1) Flood 15\%, 2) Extreme weather $10 \%, 3$ ) Flood and landslide 2\%, 4) Earthquake 5\%, 5) Extreme wave and abrasion 2\%, 6) Landslides 3\%, 7) Volcano eruption 6\%,8) Social conflicts 44\%, 9) Drought 2\%, 10) Forest and land fires 5\%, 11) Epidemics and outbreaks 6\% (East Lombok Disaster Response Plan (RPB) 2014-revised 2015). Based on data above the flood is a natural disaster that has the largest percentage.

Flood is a routine natural disaster in East Lombok. Flood inundation in East Lombok every year occurs 4 times, such as floods that occurred on February 11, 2017 washed away 13 houses, 2 totally destroyed and 11 houses some buildings drift in Suela village Suela village also flooded, recorded as many as 442 houses flooded and things this disrupts the routine of society and the paralyzed learning activities as well as offices in flood locations. Floods also occur in Sembalun and Sambelia sub-districts and destroying road infrastructure, cultivators and residents' houses. The flash floods killed 1 person, 503 people displaced, one bridge was broken, damaged 77 houses and 450 hectares of rice fields. Floods caused by heavy rain for more or less 4 days and resulted in overflowing river water. (ANTARA News 2017). Looking at several rows of flood disaster events that occurred in several sub-districts in East Lombok district, many public opinion said that lack of responsiveness and slow efforts by the government in handling floods. It indicates the weakness of the government role in reducing the risk of flood disaster in East Lombok regency appropriately, therefore need an effort to avoid the occurrence of disaster and reduce the risk of flood disaster, in other words the need of flood disaster mitigation. Flood disaster mitigation is a series of efforts to reduce the risk of flood disaster, either through physical development or awareness and increased capacity to cope with flood disaster threats. Mitigation efforts can be undertaken through mapping of areas with flood hazard levels and the formulation of flood mitigation policy (Paimin et al., 2009 in Hermon, 2012). Based on the above problems, the authors feel the need to do research on: 1) Characteristics of disaster-based land banjirdi East Lombok, 2) Hazard level of flood disaster in East Lombok, 3) flood disaster risk level in East Lombok Regency, 4) Direction of mitigation policy flood disaster in East Lombok Regency.

\section{Method}

The direction of the flood mitigation policy is done through secondary data analysis followed by Focus Group Discussion (FGD) through informants, the East Lombok District Administration (BPBD), Private (NGO), Experts (Higher Education) and the community. This is done to formulate policy alternatives, while policy priorities are analyzed through AHP (Analytical Hierarchy Process) techniques. The location of the research was in Sembalun sub-district and the data used in this study were primary data obtained directly from the field through observation of flood-based land characteristics and secondary data in the form of supporting data obtained from related institutions such as BAPPEDA, BPS and BPBD.

\section{Result and Discussion}

East Lombok Regency is located at coordinates 1160 - 117o East Longitude and 8o - 9o South Latitude. The total area of East Lombok is $1,605.55 \mathrm{~km} 2$ with a population of 1,153,773 people. East Lombok Regency is administratively divided into 20 districts, 13 sub-districts and 96 villages. The 
administrative boundary of East Lombok Regency covers the north with Java Sea, South with Indian Ocean, West with Central Lombok and West Lombok, East with Alas Strait. Sembalun Sub-district is one of the sub-districts located in East Lombok, this district has an area of $217.8 \mathrm{~km} 2$ with a population of 19,577 inhabitants. Characteristics of the Sembalun subdistrict of East Lombok regency has the form of mountainous/hilly land with the use of the land in the form of production/plantation forest, the interval of land characteristic level based on flood disaster is 22 which means Sembalun sub-district belongs to the bad land characteristic zone and supporting the occurrence of floods. Characteristics of the land in Sembalun Sub-district of East Lombok Regency has the form of mountainous/hilly land and the use of land in the form of production forest / plantation, hence the flood hazard interval level is 3.000 which means Sembalun Sub-district, East Lombok regency included into zone moderate hazard level, meaning the chances of a relatively moderate flood.

\section{Criteria for Flood Risk Level}

After analyzing the secondary data then checking the field, then the value of flood disaster risk level in Sembalun sub-district, East Lombok regency is 2 (two) which is in medium total risk level which means that in Sembalun District maximum area $50 \%$ of area is settlement, there is physical facility or socioeconomic, rice fields, fields, gardens, or there are only one or two aspects of the elements in one mintakat, as well as fatalities of $<10$ people and economic losses of between 10 and 100 million. Based on the results of interviews conducted, it was found that floods on February 11, 2017 killed 1 person, 503 people displaced, one bridge broken, damaged 77 houses and 450 hectares of rice fields. The community also mentioned that the floods that occurred in this area caused by heavy rain that never stopped for several days, in addition to the flow of clogged water in the river.

The public stated that the government's policy in dealing with floods in this area is less responsive and has not reached optimal yet, the government only focuses on providing assistance in the form of logistics during or after the disaster but relocation in the event of flood or disaster mitigation is not done by the government. At the time of the disaster, people quickly respond with their environment. Based on the above, the authors have compiled several policy plans that can be done by the local government. The author takes three criteria used to design the policy hierarchy, ie land characteristics, disaster response community and flood risk level.

Alternative policy based on land characteristic criteria based on AHP using expert choice technique can be seen in Figure 2 which in the figure found level of policy alternative based on land characteristic as follows:

1. Making permanent embankment $(0,223)$

2. Dissemination and simulation of flood disaster $(0,153)$

3. Provision of flood posts (0.132)

4. Establish an early warning system (0.129)

5. Create a legal umbrella on watershed management (0.099)

6. Prohibit construction on river banks $(0.077)$

7. Prepare zoning in each flood hazard zone (0.076)

8. Reduced exploitation in upstream areas $(0.056)$

9. Normalization of downstream estuary (0.054) 
Based on land characteristic criteria we can see that making permanent dikes is a top priority in flood-related policy making in East Lombok regency. This is in accordance with the findings of the field that the existing river does not yet have a permanent dike which when continuous rain occurs in East Lombok floods will quickly inundate the area on the banks of the river. Alternative policies based on the criteria of disaster response community using AHP with expert choice techniques can be seen in Figure 3 which in the picture found the level of alternative policy criteria of disaster response community as follows:

1. Establish an early warning system (0.172)

2. Dissemination and simulation of flood disaster $(0.167)$

3. Provision of flood posts (0.128)

4. Making permanent embankment $(0,123)$

5. Prepare zoning in each flood hazard zone (0.113)

6. Prohibit development on river banks (0.108)

7. Create a legal umbrella on watershed management $(0.075)$

8. Reduced exploitation in upstream areas $(0.059)$

9. Normalization of downstream of river mouth $(0,056)$

Based on the criteria of disaster response community we can see that building an early warning system is a top priority in flood-related policy making in East Lombok regency. This is in accordance with the findings of the field that the community is often not ready with sudden floods, early warning of flooding in this location is very necessary to see the coops and findings that exist in the field. Alternative policies based on flood risk criteria using AHP with expert choice techniques can be seen in Figure 4 which in the figure found level of policy alternative based on flood risk level as follows:

1. Making permanent embankment $(0,170)$

2. Dissemination and simulation of flood disaster (0.156)

3. Provision of flood posts (0.129),

4. Establishment of an early warning system (0.129)

5. Prepare zoning in each flood hazard zone (0.106)

6. Create a legal umbrella on watershed management $(0.083)$

7. Reduced exploitation in upstream area (0.077),

8. Normalization of downstream of river mouth (0.077)

9. Prohibit construction on river banks $(0.071)$

Based on the criteria of flood risk level we can see that making permanent dikes is a top priority in flood-related policy making in East Lombok regency. This is in accordance with the findings of the field that the existing river does not yet have a permanent dike which when continuous rain occurs in East Lombok floods will quickly inundate the area on the banks of the river. This will cause huge losses every flood hit the area, no tangguyl that inhibits the rapid water that evaporates from the river

\section{Conclusion}

Based on the results of the research, Sembalun sub-district, East Lombok regency is an area with poor land characteristics and supports the occurrence of flood disaster, in terms of flood hazard level, including in the criteria of moderate flood hazard and has a total level of total risk. Policy priorities that can be considered in decision making in relation to flood mitigation in Sembalun sub-district, East Lombok regency based on 3 criteria that exist using AHP are 1) Based on land characteristic criteria, among others: a) Making permanent embankment, b) Dissemination and disaster simulation flood, c) Provision of flood posts.2) Based on the criteria of disaster response community, among others: a) Establishment of early 
warning system, b) Disaster flood socialization and simulation, c) Provision of flood posts. 3) Based on the criteria of flood risk level, among others: a) Making permanent embankment, b) Disaster flood socialization and simulation, c) Provision of flood posts and building early warning system.

\section{References}

Badan Perencanaan dan Pembangunan Daerah (Bappeda). (2012). Rawan Bencana Indonesia. Jakarta. Badan Nasional Penanggulangan Bencana.

Barendecht H Marlies, Viglione Alberto, Gunter Bioschi. (2017). ”a Dynamic Framework Flood Risk”. Page 3-11 Volume 1. Elsevier.

BNPB. (2013). Indeks Risiko Bencana Indonesia. Jakarta. Badan Nasional Penanggulangan Bencana.

Hermon, Dedi. (2008). Metode dan Teknik Penelitian Geografi Tanah. Padang: Yayasan Jihadul Khair Center.

Hermon, Dedi. (2009). "Dinamika Permukiman dan Arahan Kebijakan Pengembangan Permukiman pada Kawasan Longsor di Kota Padang”. Disertasi. IPB Bogor.

Hermon, Dedi. (2012). Mitigasi Bencana Hidrometeorologi. Padang: UNP Press.

Indradewa, Meilani Safira. (2008). "Potensi dan Upaya Penanggulangan Bencana Banjir Sungai Wolowona, Nangaba, dan Kaliputih di Kabupaten Ende". Tesis. Pascasarjana Universitas Sebelas Maret Surakarta.

Peraturan Menteri Pekerjaan Umum No. 63/PRT/1993 tentang Pengendalian Pemanfaatan Ruang di Kawasan Rawan Bencana Banjir.

Peraturan Menteri dalam Negeri No. 33 Tahun 2006 tentang Pedoman Umum Mitigasi Bencana.

Subiyantoro, Iwan. (2010). “Upaya Mengantisipasi Bencana Melalui Kekuatan Berbasiskan Masyarakat”. Jurnal Dialog Penanggulangan Bencana Vol. 1 No. 2. BNPB.

Sugiono. (2013). Metode Penelitian Kombinasi (Mixed Methode). Bandung: Alfabeta.

Ulum, M. Chazienul. (2013). "Governance dan Capacity Building dalam Manajemen Bencana Banjir di Indonesia”. Jurnal Penanggulangan Bencana. Vol 4(2): 5-12.

Utomo, Bambang Budi dan Rima Dewi Suprihario. (2012). "Permintakan Risiko Bencana Banjir Bandang di Kawasan Sepanjang Kali Sampean, Kabupaten Bondowoso”. Jurnal Teknik ITS Vol. 1 No. 1. Institut Teknologi Sepuluh September. 